\title{
ResearchOnline@JCU
}

This is the author-created version of the following work:

Wakimoto, Diana K., Bruce, Christine, and Partridge, Helen (2013) Archivist as activist: lessons from three queer community archives in California. Archival Science, 13 (4) pp. 293-316.

Access to this file is available from:

https://researchonline.jcu.edu.au/55426/

Copyright 2013 Springer

Please refer to the original source for the final version of this work:

http://doi.org/10.1007/s10502\%2D013\%2D9201\%2D1 
The Case of LLACE: Challenges, Triumphs, and Lessons of a Community Archives

\section{The Case of LLACE: Challenges, Triumphs, and Lessons of a Community Archives}

Activism, social justice, and community involvement in the archives have become hot topics as of late, ${ }^{1}$ but activism is nothing new for community archivists and volunteers. For decades members of marginalized groups have collected, preserved, and curated collections of materials for and by communities through the work of individual activist archivists. For underrepresented groups the creation of community archives was a political act in defiance of marginalization. ${ }^{2}$ Furthermore, community archives were a way to provide a safe space for community members to come together for study, leisure reading, and socializing. This article extends our understanding of critical issues of relevance to the entire profession found in the literature by using a small queer community archives as a case study. These issues include: why founding a queer community archives was necessary; the role played by community members in creating and maintaining the archives; the development of collections and descriptive practices; and the on-going challenges of sustaining community archives.

The Lavender Library, Archives, and Cultural Exchange of Sacramento, Incorporated (hereafter referred to by its acronym, LLACE) provides a useful case to expand our

\footnotetext{
${ }^{1}$ Anne Gilliland, “Neutrality, Social Justice and the Obligations of Archival Education and Educators in the Twenty-First Century,” Archival Science 11 (2011): 193-209; Randall C. Jimerson, Archives Power: Memory, Accountability, and Social Justice (Chicago, IL: Society of American Archivists, 2009), 237.

${ }^{2}$ Andrew Flinn, Mary Stevens, and Elizabeth Shepherd, “Whose Memories, Whose Archives? Independent Community Archives, Autonomy and the Mainstream,” Archival Science 9 (2009): 74; Mary Stevens, Andrew Flinn, and Elizabeth Shepherd, "New Frameworks for Community Engagement in the Archives Sector: From Handing Over to Handing on,” International Journal of Heritage Studies 16 (2010): 59-76.
} 
The Case of LLACE: Challenges, Triumphs, and Lessons of a Community Archives

understanding of these issues in community archives and archival practice. ${ }^{3}$ Created in 1998 by a small group of dedicated activists and volunteer librarians, LLACE has become a community center serving the Sacramento area through its archival collections, circulating library of books and videos, and public programming. LLACE not only documents the rich cultural heritage of queer communities throughout the Sacramento area, it also provides meeting rooms for multiple groups, making it a popular gathering place. Located in northern California, LLACE is not in an epicenter of queer rights activism, as compared to neighboring San Francisco which is home to the larger and more well-known GLBT Historical Society. However, as the state’s capital, Sacramento is important legislatively and therefore a study of LLACE can provide a new geographic focus for community archives research. Also, as LLACE is much newer and smaller than the more famous ONE: National Gay and Lesbian Archives in Los Angeles and the Lesbian Herstory in New York, an understanding of its experience expands our appreciation of queer community archives beyond these better-known organizations.

The word "queer" is used throughout this article as the most general, overarching term to describe communities and individuals who support and make possible the LLACE. As Marcel Barriault and Rebecka Sheffield explained as guest editors of a special section on queer archives in Archivaria, they opted for the term queer for its inclusiveness and practicality. ${ }^{4}$ Susan Stryker and Jim Van Buskirk also used queer in their book Gay by the Bay: A History of Queer Culture in the San Francisco Bay Area because they felt that it encompassed identities, genders, and

\footnotetext{
${ }^{3}$ The authors would like to thank Ron Grantz and Buzz Haughton of LLACE for their generous sharing of their time and experiences. The authors would also like to especially thank Ron Grantz who reviewed an earlier version of this article.

${ }^{4}$ Marcel Barriault and Rebecka Sheffield, “Special Section on Queer Archives: Note From the Guest Editors,” Archivaria 68 (2009): 120.
} 
The Case of LLACE: Challenges, Triumphs, and Lessons of a Community Archives

sexualities not included in popular initialisms, such as LGBT. ${ }^{5}$ Stryker also used queer in her Transgender History because it denoted commonalities within communities and, as she put it, avoided "historical nit-picking” over the terms used. ${ }^{6}$

\section{Literature Review}

Research on community archives has been expanding within the last decade and, while still arguably a nascent field of research, ${ }^{7}$ there are a number of articles published which have focused on the reasons for creating these archives, their funding and staffing, collection development, description and access practices, and challenges they face. This section highlights the current state of research in these areas and positions LLACE as case to contribute to the literature on community archives. Although community archives have been created by numerous under-represented and marginalized communities, this review emphasizes literature specific to queer community archives as that is the focus of this study and the mission of LLACE.

\section{Creating Community Archives}

Community archives are archives created by community members due to the lack of representation or access to records from their pasts. Much of the literature emphasizes how marginalized groups distrusted institutional archives after seeing how their lives had been represented or, in some instances, completely omitted. As noted by both Joan Nestle and Maxine

\footnotetext{
${ }^{5}$ Susan Stryker and Martin Van Buskirk, Gay by the Bay: A History of Queer Culture in the San Francisco Bay Area (San Francisco, CA: Chronicle Books, 1996), 5.

${ }^{6}$ Susan Stryker, Transgender History (Berkeley, CA: Seal Press, 2008), 5.

${ }^{7}$ Andrew Flinn, “Community Histories, Community Archives: Some Opportunities and Challenges,” Journal of the Society of Archivists 28 (2007): 158.
} 
The Case of LLACE: Challenges, Triumphs, and Lessons of a Community Archives

Wolfe in their histories of the Lesbian Herstory Archives, there was a great need to create a community archives to document histories that were being lost or ignored. ${ }^{8}$

Much of the literature on community archives, like queer history in general, has been written by activists and community members and only relatively recently have scholars and academics begun to seriously study and write about them. ${ }^{9}$ One of the most prominent is British researcher Andrew Flinn. His research into community archives supports the earlier writings by community archivists who stated that when mainstream archival institutions marginalized certain groups these communities created their own archives and collected materials that would otherwise have been lost to the historical record. ${ }^{10}$ Archivist Elizabeth Knowlton studied this phenomenon in the late 1980s by conducting a survey of gay community archives and institutional archives located in the same city or state. Published in 1987, her survey results showed that institutional archivists had little knowledge of gay archives or gay rights movements more generally. ${ }^{11}$ The only queer community records available in these cities were stored in individuals' homes or in community archives. ${ }^{12}$

More recent literature has shown that an important motivation behind the founding of community archives is to maintain control over the communities’ records. This has continued to

\footnotetext{
${ }^{8}$ Joan Nestle, “The Will to Remember: The Lesbian Herstory Archives of New York,” Feminist Review 34 (1990): 87; Maxine Wolfe, “The Lesbian Herstory Archives,” South African Archives Journal 40 (1998): 20-21.

${ }^{9}$ Jonathan Katz, Gay American History: Lesbians and Gay Men in the U.S.A. (New York: Thomas Y. Crowell Company, 1976), 2-3; Nestle, “The Will to Remember,” 87.

${ }^{10}$ Flinn, “Community Histories,” 154.

${ }^{11}$ Elizabeth Knowlton, “Documenting the Gay Rights Movement,” Provenance 5, no. 1 (1987): 21, 27.

${ }^{12}$ Knowlton, “Documenting the Gay Rights Movement,” 22; Steven Maynard, “'The Burning, Wilful Evidence’: Lesbian/Gay History and Archival Research,” Archivaria 33 (1991-92): 196.
} 
The Case of LLACE: Challenges, Triumphs, and Lessons of a Community Archives

be the case, even as institutional archives have begun collecting community records as well. Published interviews with community archives' founders often contain commentary on the importance of community control over archives, as noted by Ajamu X and Topher Campbell of rukus! in the United Kingdom ${ }^{13}$ in their article with Mary Stevens and Joan Nestle of the Lesbian Herstory Archives ${ }^{14}$ in New York, and William Walker of GLBT Historical Society ${ }^{15}$ in San Francisco. Interviews and other published accounts of the beginnings of queer community archives also attest to the grassroots, activist attitudes of their founders and the strong support given by community members who also desired to control their historical collections. ${ }^{16}$ As Nestle wrote about the Lesbian Herstory Archives, she and other founders wanted "our story...preserved by us.”17 Community archives’ founders’ accounts support findings in subsequent research by Flinn with his colleagues, Mary Stevens and Elizabeth Shepherd, on the importance of dedicated founders and volunteers in creating community archives to preserve history and strengthen community identities. ${ }^{18}$

\footnotetext{
${ }^{13}$ Ajamu X, Topher Campbell, and Mary Stevens, “Love and Lubrication in the Archives, or rukus! A Black Queer Archive for the United Kingdom,” Archivaria 68 (2009): 293.

${ }^{14}$ Nestle, “The Will to Remember,” 87.

${ }^{15}$ William Walker, interview by Terence Kissack, May 14, 2003, transcript, http://www.glbthistory.org/research/oh/WalkerWillie5-14-03oralhistory_web.pdf.

${ }^{16}$ X, Campbell, and Stevens, “Love and Lubrication,” 277, 292.

${ }^{17}$ Nestle, “The Will to Remember,” 87.

${ }^{18}$ Andrew Flinn and Mary Stevens, “It is Noh Mistri, Wi Mekin Histri”: Telling Our Own Story, Independent and Community Archives in the UK, Challenging and Subverting the Mainstream,” in Community Archives: The Shaping of Memory, Principles and Practice in Records Management and Archives, eds. Jeannette Bastian and
} Benjamin Alexander (London: Facet Publishing, 2009), 17-18; Flinn, Stevens, Shepherd, “Whose Memories,” 7172. 
The Case of LLACE: Challenges, Triumphs, and Lessons of a Community Archives

\section{Funding and Staffing}

The literature on community archives has shown that one of the main challenges to community archives has been the need for sustained funding and the importance of community support in maintaining the archives. Writings by archivist Marcel Barriault and community archivist Polly Thistlethwaite discuss the fact that community archives face many difficulties in funding which means they must rely heavily on community support. ${ }^{19}$ For example, Barriault reported that the Canadian Gay Archives was not granted chartable status until November 1981, as Revenue Canada ruled that because it "did not acquire government records” it did not qualify as an archives. ${ }^{20}$ In her article about the Lesbian Herstory Archives, Thistlethwaite emphasized the continuing need to rely on support from lesbian community members in order to preserve and provide access to records. ${ }^{21}$ Nestle, who was instrumental in creating the Lesbian Herstory Archives, further explains that the archives refuses to accept government funding, as its founders and volunteers do not believe the government can be relied upon and that support must come from within lesbian communities. ${ }^{22}$

\footnotetext{
${ }^{19}$ Marcel Barriault, “Archiving the Queer and Queering the Archives: A Case Study of the Canadian Lesbian and Gay Archives (CLGA)," in Community Archives: The Shaping of Memory, Principles and Practice in Records Management and Archives, eds. Jeannette A. Bastian \& Benjamin Alexander (London: Facet Publishing, 2009), 97108; Martin Meeker, “Archives Review: The Gay and Lesbian Historical Society of Northern California,” Journal of Gay, Lesbian and Bisexual Identity 4, no. 2 (1999): 197-205; Polly J. Thistlethwaite, “Building 'A Home of Our Own’: The Construction of the Lesbian Herstory Archives,” in Daring to Find Our Names: The Search for Lesbigay Library History, ed. James V. Carmichael, Jr. (Westport, CT: Greenwood Press, 1998): 153-174.

${ }^{20}$ Barriault, “Archiving the Queer,” 103.

${ }^{21}$ Thistlewaite, “Building ‘A Home of Our Own,”” 170-171.

${ }^{22}$ Nestle, “The Will to Remember,” 92.
} 
The Case of LLACE: Challenges, Triumphs, and Lessons of a Community Archives

Other writings have shown that funding comes through donations, grants, other nonprofit organizations, and non-community archives. ${ }^{23}$ For instance, Aimee Brown’s overview history of queer community archives in the United States gives the example of the GLBT Historical Society depositing collections with the San Francisco Public Library to provide greater researcher access. She also mentions other community archives that, because of sustained funding issues, donated their collections to institutional archives for safekeeping and continued public access. $^{24}$

The literature also suggests, however, that these arrangements and partnerships are not without their own issues. Partnerships can go sour, as when the Lesbian Herstory Archives created a joint exhibit with the New York Public Library. In the end, the volunteers from the Lesbian Herstory Archives felt that their work was slighted in the exhibit’s credits. ${ }^{25}$ Newman, as well as the research team of Stevens, Flinn, and Shepherd, similarly found that community archives remain skeptical of working with institutional archives. Based on their research, they suggested that organizations desiring to partner with community archivists must ensure true collaboration and respect in order to build trust and mutually beneficial programs. ${ }^{26}$

\footnotetext{
${ }^{23}$ Aimee Brown, “How Queer 'Pack rats’ and Activist Archivists Saved our History: An Overview of Lesbian, Gay, Bisexual, Transgender, and Queer (LGBTQ) Archives, 1970-2008,” in Serving LGBTIQ Library and Archives Users: Essays on Outreach, Service, Collections and Access, ed. Ellen Greenblatt (Jefferson, NC: McFarland \& Company, Inc.), 124; X, Campbell, and Stevens, “Love and Lubrication,” 291.

${ }^{24}$ Brown, “How Queer Pack Rats,” 128-130.

${ }^{25}$ Thistlewaite, “Building ‘A Home of Our Own,’” 170.

${ }^{26}$ Joanna Newman, “Sustaining Community Archives,” Aplis 24, no. 1 (2011): 42; Stevens, Flinn, and Shepherd, “New Frameworks,” 72.
} 
The Case of LLACE: Challenges, Triumphs, and Lessons of a Community Archives

Community archives’ funding has significant implications for staffing, particularly in terms of whether the archives is managed by a volunteer or paid staff. The ethnographic analysis of the British black LGBT archives known as rukus!, by X, Campbell and Stevens, found that archives’ staff members are often a mix of activists and volunteers. ${ }^{27}$ Some archives, as Nestle notes in her article on the Lesbian Herstory Archives, take great pride in training their volunteer staff in-house. ${ }^{28}$ The literature also reveals that some well-funded archives have paid professional staff, while still others, such as the LLACE, have volunteers who are professional archivists and oversee volunteers. ${ }^{29}$ This diversity in staffing and funding models is partially a product of differing levels of support of the archives.

\section{Collections and Collection Development}

Collection development in community archives, more so than in other archives, is dictated by community members. Many archives rely almost exclusively on donations from community members. The resultant archival collections reflect the passions and experiences of individual donors and often include material not traditionally considered archival records. For example, in interviews with volunteers at the rukus! Archives, Stevens found that 'zines, posters, and other ephemera were collected. ${ }^{30}$ Barriault found that the Canadian Gay Archives similarly collected ephemera, including buttons, trophies, and uniforms, as well items commonly thought of as museum pieces, such as furniture and art. ${ }^{31}$

\footnotetext{
${ }^{27}$ X, Campbell, and Stevens, “Love and Lubrication,” 284, 291.

${ }^{28}$ Thistlethwaite, “Building ‘A Home of Our Own’,” 154.

${ }^{29}$ Walker, interview.

${ }^{30}$ X, Campbell, and Stevens, “Love and Lubrication,” 286.

${ }^{31}$ Barriault, “Archiving the Queer,” 101; Flinn, “Community Histories,” 153.
} 
The Case of LLACE: Challenges, Triumphs, and Lessons of a Community Archives

These non-traditional acquisitions by some community archives have, consciously or not, aligned them with the integrative work of GLAM, an area of research that has recently seen a resurgence in popularity. ${ }^{32}$ An acronym for galleries, libraries, archives, and museums, GLAM emphasizes the interconnections among these cultural information centers and their potential to serve as holistic spaces for education and research. As Lisa M. Given and Lianne McTavish note, the conception of spaces that integrate the similar missions and features of libraries, museums, and archives dates back to at least the nineteenth century. ${ }^{33}$ Interest in GLAM is being revived in part due to the collaborative efforts of GLAM institutions in creating digital repositories. ${ }^{34}$ Jennifer Trant has studied this movement, noting its strong online presence in terms of metacollections from multiple institutions. ${ }^{35}$

While many community archives rely extensively or even exclusively on donations for expanding their collections, this does not mean that community archives do not have collection development policies. The literature shows that many community archives collections started with donations of records that might otherwise been thrown away. ${ }^{36}$ But rapid growth has strained archival resources, and now most repositories, such as the ONE: National Gay and

\footnotetext{
${ }^{32}$ Martin R. Kalfatovic, Effie Kapsalis, Katherine P. Spiess, Anne Van Camp, and Michael Edson, “Smithsonian Team Flickr: A Library, Archives, and Museums Collaboration in Web 2.0 Space,” Archival Science 8, (2008): 267.

${ }^{33}$ Lisa M. Given and Lianne McTavish, “What’s Old is New Again: The Reconvergence of Libraries, Archives, and Museums in the Digital Age,” The Library Quarterly 80, no. 1 (2010): 8.

${ }^{34}$ Ibid., 9.

35 Jennifer Trant, “Emerging Convergence? Thoughts on Museums, Archives, Libraries, and Professional Training,” Museum Management and Curatorship 24, no. 4 (2009): 369.

${ }^{36}$ Flinn, “Community Histories,” 154; Meeker, “Archives Review,” 197.
} 
The Case of LLACE: Challenges, Triumphs, and Lessons of a Community Archives

Lesbian Archives and the GLBT Historical Society, have policies which focus collecting priorities and goals. $^{37}$

\section{Description and Access}

A number of studies in archival literature have focused on descriptive standards, especially those relating to historically marginalized communities, which are of great relevance to community archives research. Begun decades ago with Sanford Berman’s 1971 piece on discrimination in the Library of Congress Subject Headings, subsequent work by Ellen Greenblatt and others has looked at ways to eliminate discriminatory and derogatory words in existing thesauri or have advocated creating alternative vocabularies to use when describing certain collections. ${ }^{38}$ For instance, Matt Johnson, in his report on “GLBT Controlled Vocabularies and Classification Schemes” for the American Library Association's GLBT Roundtable, noted that there are many controlled vocabularies created specifically for cataloguing queer collections. ${ }^{39}$ One of the best known is a thesaurus created by Dee Michel. Another issue raised in the literature concerns physical access to collections in community archives. While archives traditionally have closed stacks, some community archives

\footnotetext{
${ }^{37}$ GLBT Historical Society, “Collections Policy Statement,” last modified 2006, http://www.glbthistory.org/research/collectionstatement.html; ONE National Gay and Lesbian Archives, “Collection Policy Statement,” accessed December 7, 2009, http://www.onearchives.org.

${ }^{38}$ Sanford Berman, Prejudices and Antipathies: A Tract on the LC Subject Heads Concerning People (Metuchen, NJ: The Scarecrow Press, Inc., 1971), x; Ellen Greenblatt, “The Treatment of LGBTIQ Concepts in the Library of Congress Subject Headings,” in Serving LGBTIQ Library and Archives Users, ed. Ellen Greenblatt (Jefferson, NC: McFarland \& Company, Inc., 2011), 214-220; Hope A. Olson, “The Power to Name: Representations in Library Catalogs,” Signs: Journal of Women in Culture and Society 26, (2001): 645-646.

${ }^{39}$ Matthew Johnson, “GLBT Controlled Vocabularies and Classification Schemes,” American Library Association GLBT Roundtable, 2007, http://www.ala.org/glbtrt/popularresources/vocab.
} 
The Case of LLACE: Challenges, Triumphs, and Lessons of a Community Archives

do not. For example, the Lesbian Herstory Archives is not a closed stacks archives, but makes its materials available for browsing. ${ }^{40}$ Other community archives, especially those that collect nonarchival materials, will open certain sections of their stacks for browsing, such as LLACE. These differences in access policies, like those in description and collecting, are related to community support and needs, demonstrating again the influence of community members over the archives.

\section{Current and Future Challenges}

While researchers have found high levels of involvement in community archives, the archives still face challenges in their continued survival. As the current literature reveals, community archivists must always be developing sources of funding and finding ways to increase their visibility. Meeker noted this need in his article on the GLBT Historical Society, ${ }^{41}$ emphasizing the importance of community involvement and visibility in generating the funds needed to support the archives' work. Sustainability is one of the most pressing current and future challenge identified by researchers for community archives as they continue to serve their missions of collecting, preserving, and providing access to records by, from, and important to queer communities. $^{42}$

\section{Gaps in the Literature}

While literature on community archives' histories and practices continues to grow, there are still numerous gaps. As community archives is a relatively recent field of study, with much of the research being done outside of the United States, there are many archives that have yet to be documented. This study of LLACE fills a geographical niche by examining a community archives in a relatively under-studied location. Also, while histories of multiple community

\footnotetext{
${ }^{40}$ Nestle, “The Will to Remember,” 88.

${ }^{41}$ Meeker, “Archives Review,” 205.

${ }^{42}$ Barriault, “Archiving the Queer,” 105; Meeker, “Archives Review,” 204.
} 
The Case of LLACE: Challenges, Triumphs, and Lessons of a Community Archives

archives have been recorded in first-hand accounts by their founders and in studies by archivists and historians, there has been limited literature on applying the findings to archival practice, outside of the work by Flinn, Stevens, and Shepherd. This study of LLACE attempts to partially fill this gap by using the archival work being done at LLACE to push forward the discussion of evolving professional archival practices.

\section{Discussion}

LLACE provides an exemplary case for exploring issues raised in the literature and expanding our understanding of community archives and their intersections with other types of repositories. This study used oral history interviews with LLACE’s archivist, Ron Grantz, and lead cataloger, Buzz Haughton, as well as archival collections and newspaper articles. Ron Grantz also provided copies of LLACE's collection policy and a speech he wrote on LLACE's history and current status. This discussion section looks at each of the key issues raised in the literature review as it relates to LLACE.

Key Issue 1: Creation of LLACE as Dedicated Space

Previous researchers have noted almost universally that one of the primary reasons for creating community archives was because institutional archives were not collecting and providing access to community records. ${ }^{43}$ This was true for LLACE, which was established on June 21, 1998, as the Sacramento Library Project, and incorporated as a 501(c) (3) non-profit organization. ${ }^{44}$ LLACE's mission was to provide a library and archives for the city's queer community members, which Sacramento lacked. At the time, the Jayne Rountree Commemorative Library and its host organization, the Lambda Community Center, were

\footnotetext{
${ }^{43}$ Brown, “How Queer 'Pack rats',” 130.

44 “Sacramento Library Project,” Mom Guess What (Sacramento, CA), July 1, 1998, 7.
} 
The Case of LLACE: Challenges, Triumphs, and Lessons of a Community Archives

undergoing great financial difficulties which imperiled the viability of a dedicated space for collecting materials by and about communities in Sacramento. ${ }^{45}$ This uncertainty was a great blow to community members as there were no other dedicated spaces in the Sacramento area for the collection, preservation, and sharing of records by and for queer community members. Therefore the creation of such an organization as LLACE was needed in order to provide a space and visibility to the collections and work of community members. As an article appearing in the July 1, 1998, issue of the newspaper, Mom Guess What, explained, the purpose of creating the archives was to preserve "artifacts that document our rich cultural heritage" through this new community-based organization. ${ }^{46}$

LLACE was the brainchild of Gail Lang, who persuaded many people to help with her plan to create a resource center for Sacramento's queer communities. Lang studied nursing and was an occupational therapist in New York before moving to California in 1979 and becoming an employee at The Open Book, a LGBTQI (lesbian, gay, bisexual, transgender, queer, intersex) bookstore. ${ }^{47}$ LLACE was Gail Lang's vision, but establishment required much community support. For example, during the library's formative years, Lang was helped by many individuals including Michael Bennett ${ }^{48}$ and Kimberly Weer. ${ }^{49}$ Bennett had been involved with the Rountree

\footnotetext{
45 “Lambda Center Makes Last Ditch Effort,” Mom Guess What (Sacramento, CA), May 15, 1998, 4. ${ }^{46}$ Ibid.

${ }^{47}$ Legislative LGBT Caucus \& Lavender Library, Archives and Cultural Exchange of Sacramento, Inc. Remember the Contributions of Gay, Lesbian, Bisexual and Transgender Californians: The June 2006 Pride Exhibit Program. 2006. San Francisco LGBT Groups Ephemera Collection, GRP EPH, The Gay, Lesbian, Bisexual, Transgender Historical Society, San Francisco, CA.

${ }^{48}$ Amy Yannello, “Last Days of Gail Lang: A Local Icon brings the Gay and Lesbian Community Together,” Sacramento News \& Review, November 3, 2003, accessed August 31, 2011, http://www.newsreview.com.
} 
The Case of LLACE: Challenges, Triumphs, and Lessons of a Community Archives

Library while it was part of the Lambda Community Center (another queer community organization in Sacramento), ${ }^{50}$ while Weer was one of the first presidents of the LLACE's Board of Directors. But it was Lang's personal connections that enticed many other people to assist with the LLACE's formation and later volunteer. As Buzz Haughton, current LLACE Board treasurer and lead cataloger, said, "I think a lot of people who became active in the Lavender Library did it out of a sense of loyalty to Gail because we loved her so much.” ${ }^{51}$ Indeed, Lang has been described as the library’s "guardian angel." ${ }^{52}$ Due to Lang and other community members’ unflagging effort, LLACE would quickly become an archives, library, and popular community gathering space.

Key Issue 2: Budget and Staffing

LLACE faces the same budgeting and staffing issues as noted in previous studies on community archives. Its archives, along with its circulating collections, operates on a shoestring budget or, as LLACE’s archivist Ron Grantz noted, “We don’t really have a budget here. So if you need something, within reason, they'll [the board] order it. Many times we just chip in our own." 53 To address these financial issues, LLACE obtained certification from the United Way to become eligible for donations. ${ }^{54}$ Certification also meant that LLACE could receive matching

\footnotetext{
49 “Lavender Library Grand Opening,” Mom Guess What (Sacramento, CA), May 19, 1999, 5.

50 “Roundtree[sic] Library Important,” Mom Guess What (Sacramento, CA), May 1, 1998, 3.

${ }^{51}$ Buzz Haughton, interview by Diana K. Wakimoto, March 26, 2011.

52 Ibid.

${ }^{53}$ Ron Grantz, interview by Diana K. Wakimoto, March 26, 2011.

${ }^{54}$ Haughton, interview.
} 
The Case of LLACE: Challenges, Triumphs, and Lessons of a Community Archives

donations from state workers, providing another funding stream. ${ }^{55}$ A major source of income comes from the Gail Lang Trust Fund, created by Lang before her death in 2003 which, according to Haughton, consisted of "one-quarter of the value of her property." 56 This trust fund provides a safety net for LLACE, one that it has had to use by taking out part of the principal to pay for expenses. Other monies come from grants and donations from private individuals and local organizations, such as the Sacramento Valley Leathermen and Sacramento Valley Bears. ${ }^{57}$ A final source of funding comes from membership dues paid by the Pride Preservers. ${ }^{58}$ Pride Preservers are members of LLACE who donate money and time to ensure the organization's continued success. When first developed there were five levels of membership based on amount donated, with each amount equated to different borrowing privileges for the lending library. For example, at the yellow level a member would have donated twenty-five dollars and would be able to check out two items at a time. At the purple level, a member would have donated one hundred dollars and be able to check out five items at a time. ${ }^{59}$ There are now two levels of Pride Preservers, and these membership dues enable LLACE’s continued operation. ${ }^{60}$

\footnotetext{
${ }^{55}$ Nicole Macshafi, “Moving History: Sacramento’s Relocates to Lavender Heights,” Mom Guess What (Sacramento, CA), Sept. 15, 2000, 21.

${ }^{56}$ Haughton, interview.

${ }^{57}$ Ibid.

${ }^{58}$ Macshafi, “Moving History,” 21.

${ }^{59}$ Lavender Library, Archives, and Cultural Exchange of Sacramento, Inc. Brochure, ca. 2000, San Francisco LGBT

Groups Ephemera Collection, GRP EPH, The Gay Lesbian, Bisexual, Transgender Historical Society, San Francisco, CA.

${ }^{60}$ Haughton, interview.
} 
The Case of LLACE: Challenges, Triumphs, and Lessons of a Community Archives

LLACE has an all-volunteer board that directs the day-to-day operations and plans for its future. The board is comprised of six positions: President, Vice President/President Elect, Secretary, Treasurer, the Volunteer Coordinator, and Archivist. ${ }^{61}$ LLACE's board has regular meetings during which it shapes the direction of the organization. In 2011, the board began work on a five-year plan to determine its organizational goals and strategies to reach these goals. ${ }^{62}$ The primary goals of the new plan are to make the organization self-sustaining and more attractive to potential donors and grant organizations. As the LLACE is still quite young, defining its goals is critical so that its limited resources are used to support activities deemed most important by its members and volunteer staff.

Key Issue 3: Collecting and Collection Development

Except for a small collection development fund for videos and the yearly subscription to The Advocate, LLACE's collection continues to grow exclusively through donations, again emphasizing the importance of community support. A good example of this support is LLACE's clippings file of newspaper articles about queer communities. As Haughton, explained in his interview, LLACE receives many of its clippings from

...one elderly friend of ours, a member, in Davis who subscribes to the Sacramento Bee and the Davis Enterprise. Anything LGBT related he clips out and gives to me. I have dinner with him once a month and he gives me everything he’s clipped out and it goes into our clippings file. ${ }^{63}$

\footnotetext{
${ }^{61}$ Ibid.

${ }^{62}$ Grantz, interview.

${ }^{63}$ Haughton, interview.
} 
The Case of LLACE: Challenges, Triumphs, and Lessons of a Community Archives

According to Haughton, these clippings files are used "a fair amount” by high school and college students. ${ }^{64}$ In this one way, LLACE functions as an archival repository for local history utilized by students who may or may not self-identify with being queer. This clippings file also provides another reason for social interaction between members and is one way in which LLACE functions not only as an archival repository, but also as a community gathering space.

Collections are the heart of community archives, and the collections at LLACE are no different. By the time LLACE had its grand opening celebration on May 22, $1999,{ }^{65}$ its collection numbered over one thousand books as well as periodicals and videotapes. By September 2000, LLACE had over 3,000 volumes, including "Le Theatre Lesbian archives of original plays,” copies of the Daughters of Bilitis’ magazine, the Ladder, and newsletters from the Mattachine Society. ${ }^{66}$ The archives had also acquired a wide variety of ephemera and memorabilia, including posters, fliers, buttons, and postcards. ${ }^{67}$ Having received a small grant from the Lambda Freedom Fair to purchase books, LLACE had begun collecting in the area of “transgender, children, youth and ethnic gay studies" ${ }^{68}$ as well. In its early collecting LLACE was affirming its commitment to document communities that had been neglected by institutional archives and libraries.

\footnotetext{
${ }^{64}$ Ibid.

65 “Lavender Library Grand Opening,” 5.

${ }^{66}$ Macshafi, "Moving History,” 21.

${ }^{67}$ Lavender Library, Archives, and Cultural Exchange of Sacramento, Inc. Brochure, January 30, 2000, San Francisco LGBT Groups Ephemera Collection, GRP EPH, The Gay Lesbian, Bisexual, Transgender Historical Society, San Francisco, CA.

68 “Lavender Library Grand Opening,” 5.
} 
The Case of LLACE: Challenges, Triumphs, and Lessons of a Community Archives

LLACE's founders were very aware of the communities’ concerns for the long-term preservation and safeguarding of these irreplaceable materials, especially in light of troubles faced by other local nonprofits within Sacramento's communities, such as the Lambda Community Center and its Rountree Library. In a September 2000 article in Mom Guess What, founder Gail Lang emphasized LLACE's commitment to preserving diverse records of queer communities and protecting the collections so people would not have to worry about "their prized possessions.” ${ }^{69}$ Lang promised that the donations received by LLACE would be cherished and would "be there for everyone!" ${ }^{70}$ To allay donor concerns, LLACE's articles of incorporation provided for the donation of its collections to another queer community archives, such as the GLBT Historical Society in San Francisco, should LLACE be forced to close. ${ }^{71}$ This was a far-sighted move by LLACE to ensure the safekeeping of communities’ materials.

The volunteers' enthusiasm for collecting and preserving records of the queer communities was unflagging, and it was no surprise that LLACE's collections grew quickly, proof of the active donations from the community. ${ }^{72}$ After only a year at its original location on B Street, LLACE had outgrown its space and was looking for a new place to house its collections. LLACE members found appropriate space in mid-town Sacramento, their present location on 21st Street, which has allowed the organization to continue to expand.

Because LLLACE functions as more than a traditional library or archives with both circulating and non-circulating collections, its collection policy covers both aspects. The policy

\footnotetext{
${ }^{69}$ Macshafi, “Moving History,” 21.

${ }^{70}$ Nicole Macshafia, “LLACE Open House ‘Was a Grand Success!’” Mom Guess What (Sacramento, CA), December 1, 2000, 5 .

${ }^{71}$ Ibid.

${ }^{72}$ Macshafi, “Moving History,” 21.
} 
The Case of LLACE: Challenges, Triumphs, and Lessons of a Community Archives

clearly defines the collecting scope to include "book and non-book material” pertaining to queer communities. ${ }^{73}$ Interestingly, LLACE’s policy makes it explicit that “non-gay authors writing fiction and nonfiction" about queer communities are "very acceptable to add to the collection.",74 In this way, LLACE demonstrates its openness to non-queer groups. LLACE's collection policy also notes that its geographical focus is the "Sacramento area gay and lesbian community" as well as indicates that the archives collects the "papers and materials of ordinary LGBT people.” LLACE’s board justifies this policy, explaining that ordinary people "have stories to tell. Lavender Library is dedicated to preserving these important records.” ${ }^{75}$ This inclusivity allows LLACE to document the richness of queer communities in Sacramento and not limit the collection to only the communities’ most notable or elite members and organizations.

\section{Key Issue 4: Description and Access}

In one of its early brochures, LLACE provided details about its catalog and how it used a thesaurus created by Dee Michel specifically for queer libraries and archives to classify and catalog its materials. ${ }^{76}$ As the brochure explained, this specialized "classification system" enabled members to catalog the collections in a way that enabled "access to our uniqueness and diversity." 77 In contrast to the Library of Congress Subject Headings, which had issues with

\footnotetext{
${ }^{73}$ Lavender Library, Archives, and Cultural Exchange of Sacramento, Inc., Materials Collection Policy, n.d., 1.

${ }^{74}$ Ibid.

${ }^{75}$ Ibid.

${ }^{76}$ Lavender Library, Archives, and Cultural Exchange of Sacramento, Inc. Brochure.

${ }^{77}$ Ibid.
} 
The Case of LLACE: Challenges, Triumphs, and Lessons of a Community Archives

antiquated and/or discriminatory language, the thesaurus by Michel is easy to use and expand in response to local needs. ${ }^{78}$

Although community members have donated historical materials to the LLACE since its founding in 1998, it was not until 2005 that any processing of them was completed. Before a trained archivist began volunteering, Haughton admitted, the archival collections "had lain dormant because none of us had the archival background to make it real." ${ }^{79}$ Currently, Ron Grantz is LLACE's archivist and responsible for collection development, along with the physical processing and description of the collections. Like everyone at LLACE, he is a volunteer. Prior to joining the LLACE in 2005, Grantz spent over twenty-seven years as librarian at the Detroit Public Library and nine years as Librarian/Archivist Chief of Department of the National Automotive History Collection. ${ }^{80}$ Retiring in 1994, Grantz and his partner moved to Sacramento the following year and opened The Open Book. ${ }^{81}$ Interestingly, even though Grantz did not become involved in LLACE until 2005, he knew Gail Lang for many years as she was an employee at his bookstore. This is another example of how personal connections within queer communities support and sustain organizations like LLACE.

LLACE does not participate in the Online Archive of California (OAC), the major union catalog of archival repositories in California. This gives LLACE freedom to catalog and describe its collections using alternative standards. Instead of using the OAC template, Grantz and the volunteers he supervises model their finding aids on those from his alma mater, Wayne State

\footnotetext{
${ }^{78}$ Sanford Berman, Prejudices and Antipathies,182; Greenblatt, “The Treatment of LGBTIQ Concepts,” 213-214; Haughton, interview.

${ }^{79}$ Haughton, interview.

${ }^{80}$ Grantz, interview.

${ }^{81}$ Ron Grantz, “Personal History Outline,” Speech, 2008.
} 
The Case of LLACE: Challenges, Triumphs, and Lessons of a Community Archives

University. ${ }^{82}$ Though they are not in Encoded Archival Description (EAD), the finding aids are familiar in format to anyone who has done any research in archives.

Because LLACE is not part of the OACE, its archival finding aids do not rely solely on the OAC's preferred descriptive standard, the Library of Congress Subject Headings (LCSH). Instead, LLACE employs the classification system created by Dee Michel for describing queer materials as well. LLACE volunteers have found Michel's thesaurus easy to use, and it can be expanded with additional local headings as needed. As Haughton succinctly put it, "Why not make it as usable as possible?” ${ }^{83}$ Interestingly, while the LLACE’s circulating library catalogs books solely using Michel’s thesaurus, its archival finding aids list subject headings from Michel's thesaurus first followed by the LCSH terms. This will be of great value if LLACE decides in the future to become part of the OAC. It also demonstrates the ubiquitous nature of LCSH, despite past criticisms of its omissions and biases.

A pressing issue due to the archives’ financial constraints concerns space. Because storage space is quite limited at LLACE, none of the archival collections are maintained at its 21st Street location. ${ }^{84}$ This means that researchers must make an advance appointment to use the archival collections so that the volunteers have time to retrieve them from offsite storage. However book, journal, and video collections are available on-site for browsing and borrowing.

Even with space and financial issues, LLACE has always offered its facility for other groups to use. Haughton mentioned in his interview that Eclectic? Trash? (a book group), Sacramento Valley Veterans (a LGBT veterans group), and a transgender group all meet at the library on a monthly basis. The library also hosts occasional book signings and readings.

\footnotetext{
${ }^{82}$ Grantz, interview.

${ }^{83}$ Haughton, interview.

${ }^{84}$ Grantz, interview.
} 
The Case of LLACE: Challenges, Triumphs, and Lessons of a Community Archives

Moreover, according to Haughton, public use of LLACE is "not limited to sexual orientation. Anybody could come in here and ask us for space. And all it takes is approval from the board.” 85 Key Issue 5: Sustainability

Partnerships enable the archives' staff and volunteers to be more connected to the wider communities. Interestingly, LLACE and the GLBT Historical Society in San Francisco have been connected to each other from LLACE's founding when the Historical Society lent materials to LLACE for an exhibit titled “Celebrating California: Admission Day 2000.”86 LLACE and the GLBT Historical Society are also connected via the papers of former state lobbyist, George Raya. Although according to Grantz the bulk of Raya's papers are in Sacramento, “a little bit is in San Francisco, a little bit is in San Diego.” ${ }^{87}$ The GLBT Historical Society currently displays its “little bit” at the new GLBT History Museum in San Francisco’s Castro District. ${ }^{88}$ These partnerships take time and funding to nourish and are an ongoing aspects of LLACE's work. LLACE also participates in collaborations with other institutions in documenting queer history. For example, archivist Ron Grantz noted that LLACE is “a contact organization” for IMPACTSTORIES, a statewide oral history project with gay and lesbian Californians who were politically active from the 1960 s to the 1980 s. $^{89}$

In addition to creating more partnerships, LLACE is working to increase its visibility within the greater Sacramento area in order to remain a viable organization. Reflecting on its

\footnotetext{
${ }^{85}$ Haughton, interview.

${ }^{86}$ Gail Lang, “LLACE Shows Pride in Display,” Mom Guess What (Sacramento, CA), October 1, $2000,2$.

${ }^{87}$ Grantz, interview.

${ }^{88}$ Katherine Seligman, “New Gay Museum Opens in S.F.’s Castro: ‘Unique Cultural Resource’ has Range of Exhibits,” The Sacramento Bee (Sacramento, CA), February 27, 2011, 3.

${ }^{89}$ Grantz, interview.
} 
The Case of LLACE: Challenges, Triumphs, and Lessons of a Community Archives

lack of a public presence, Haughton admitted, “I don’t know how word gets out. The local library schools, San José State and Drexel know about us. And maybe people come in that way." ${ }^{90}$ He mentioned that the library and archives get "calls or emails from all over," even from as far away as Zambia and Uruguay. ${ }^{91}$ However, Haughton goes on to explain, "We cannot afford publicity so unless we get free publicity, we don’t get publicity." ${ }^{92}$ According to Haughton, lack of visibility translates into a lack of funding: “...if we want to get on the radar and start attracting funding, we really need to work on publicity as well as fundraising — both of them. The two go together...."93 LLACE’s supporters hope that the proposed five-year plan will help in this regard. As Grantz indicated, once LLACE's mission and goals have been articulated, "then we have to do outreach to the different groups in Sacramento" to raise funds. ${ }^{94}$

In addition to developing a strategic plan, LLACE is designing multiple new programs and projects to increase visibility. For instance, on October 1, 2011, LLACE was one of the participating archives in the Archives Crawl 2011. During this event, four large institutions (Center for Sacramento History, Sacramento Public Library, California State Archives, and California State Library) hosted smaller archives for the day, and these archives were able to promote their collections to the wider communities in Sacramento. ${ }^{95}$ Community members received a "passport" that was stamped at each of the host institutions they visited during the event. In the near future, the library is planning on offering "Lavender Tours.” As Grantz

\footnotetext{
${ }^{90}$ Haughton, interview.

${ }^{91}$ Ibid.

92 Ibid.

${ }^{93}$ Ibid.

${ }^{94}$ Grantz, interview.

${ }^{95}$ Sacramento Archives Crawl Committee, Passport: Explore History: Sacramento Archives Crawl 2011, 2011.
} 
The Case of LLACE: Challenges, Triumphs, and Lessons of a Community Archives

explained, these will be tours of LLACE during which volunteers will talk about the circulating and archival collections, ending with coffee and donuts. These tours are based on the Habitat for Humanity tours that similarly aim to raise funds. Grantz has volunteered with Habitat for Humanity, which is where he got the idea. ${ }^{96}$ These are just two of the ways that LLACE is reaching out to the communities to increase visibility.

Another significant factor in the archives' sustainability is continuing community support. ${ }^{97}$ Haughton worries about the younger generations’ lack of interest in the archives and the communities' histories. "The majority of the people who come through the door," he observed, "are older people,” not young adults who should be the next generation of volunteers and staff. ${ }^{98}$ Hopefully, with higher visibility through programming and special events and an increased online presence, LLACE will attract the interest of the next generation.

\section{Implications}

This discussion of LLACE has important implications for both community archives and wider archival practice. The history and development of Sacramento’s queer archives reveals why marginalized communities, as late as 1998, still felt the need to create a separate archives space that was lacking at the time in Sacramento and raises important issues concerning collection development, access, and description. The study of LLACE also shows some of the challenges faced not only by community archives, but most archives, in terms of funding and relevancy to communities they serve. This section discusses how the archives profession may apply the information gained from the study of LLACE to further archival practice.

\footnotetext{
${ }^{96}$ Grantz, interview.

${ }^{97}$ Flinn, Stevens, and Shepherd, "Whose Memories," 79.

${ }^{98}$ Haughton, interview.
} 
The Case of LLACE: Challenges, Triumphs, and Lessons of a Community Archives

As LLACE shows, even in the late 1990s people still felt the need to create a space of their own to collect, preserve, and provide access to records of queer communities. While community archives provide a safe space for people to come together to learn about their pasts and share in creating their futures, this should not happen because people feel excluded from institutional archives in academic, public, and government organizations. Institutional archivists must, to quote Brenda Marston, strive to overcome the "elite, exclusionary image of archives in general," ${ }^{99}$ and develop ways to connect with traditionally marginalized members of their communities. Likewise, as scholars such as K. J. Rawson advocate, archivists must do more to become inclusive. ${ }^{100}$ Archivists can achieve such inclusivity by working in the areas highlighted throughout this article, most notably by partnering with community members to ensure fair representation and continuing to advocate for appropriate descriptors to use in describing community collections.

\section{Inclusivity through Working with Communities}

Communities, and their collections, are at the heart of community archives and one of the greatest areas of potential for improving archival practice is determining how all archives can increase community involvement. Community archives, like LLACE, survive through the intense dedication of their members and volunteers. Because community members are invested in the success of the archives, these archives reflect the communities' passions, interests, and needs. Archivists have much to learn from community archives about making their repositories an integral part of their own communities. This may mean extending the collecting scope of an

\footnotetext{
${ }^{99}$ Brenda Marston, “Lesbian and Gay Materials in Cornell’s Collection on Human Sexuality,” in Gay and Lesbian Library Service, eds. Cal Gough and Ellen Greenblatt (Jefferson, NC: McFarland \& Company, Inc., 1990$), 67$. ${ }^{100}$ K. J. Rawson, “Archiving Transgender: Affects, Logics, and the Power of Queer History” (doctoral dissertation, Syracuse University, 2010), 90-91, 96-97.
} 
The Case of LLACE: Challenges, Triumphs, and Lessons of a Community Archives

archives and/or partnering with community archives to share resources, showcase joint exhibits, or exchange information. As Stevens, Flinn, and Shepherd ${ }^{101}$ have shown, there are many ways for archivists to work with community archives to ensure inclusivity in archival collections and create stronger partnerships among multiple types of archives.

Inclusivity through Advocating for Appropriate Description

As noted in the discussion of LLACE's description of collections, community archivists often use both LCSH and a specialized thesaurus in their finding aids. Description is a very powerful controller of how communities and individuals are represented in the archives and community archives are mindful and deliberate in their descriptions of records from community members and organizations. Working with community members and community archivists can help ensure that descriptions and descriptive standards are created and used in ways that respectfully represent the communities’ records. ${ }^{102}$ Collaboration can also put more pressure on archival bodies to continually update entrenched descriptive standards like LCSH so that the terminology used reflects the language used by the communities they represent. ${ }^{103}$

\section{Future Directions of Research}

The subject of community archives is a promising area of study with numerous avenues for future research. One exciting approach is to undertake comparative studies of community archives across different communities and across different countries. These comparative studies may enable us to understand the similarities and differences among archives and suggest best practices not only for community archives but for the profession in general. Comparative

\footnotetext{
${ }^{101}$ Stevens, Flinn, and Shepherd, “New Frameworks,” 72.

${ }^{102}$ Katie Shilton and Ramesh Srinivasan, "Participatory Appraisal and Arrangement for Multicultural Archival Collections,” Archivaria 63 (2007): 87, 94-95.

103 Johnson, “GLBT Controlled Vocabularies.”
} 
The Case of LLACE: Challenges, Triumphs, and Lessons of a Community Archives

research would also extend the work of Stevens, Flinn, and Shepherd ${ }^{104}$ and suggest how and why some community archives thrive while others struggle and sometimes are forced to close.

Another potential area of scholarly and professional study concerns the continued analysis of archival description. Description is a very powerful controller of how communities and individuals are represented in the archives, and in the past descriptive standards, like LCSH, have not empowered minorities, women, or members of queer communities. ${ }^{105}$ More research is needed to document changes in language usage and ensure that descriptive standards change to reflect current and appropriate language when describing collections.

As noted in the literature review and shown through the collections of LLACE, community archives are more than traditional archival spaces and collections, often serving as a library, archives, and museums within the same space. As such, community archives already embody the concept of GLAM by combining elements of all four types of information and cultural organizations. However, even though researchers report that we are starting to see collaborations and overlap in areas such as online collections, we have yet to see overlap in other areas such as curriculum for teaching new professionals in this re-integrated landscape. ${ }^{106}$ Much research is still needed in this reemerging field of study, ${ }^{107}$ especially into how community archives can contribute to the understanding of GLAM integration in collection development and beyond in practice in both physical and digital spaces. As more researchers and organizations become interested in examining how intersections among GLAM organizations may help

\footnotetext{
${ }^{104}$ Stevens, Flinn, and Shepherd, “New Frameworks,” 59-76.

105 Greenblatt, “The Treatment of LGBTIQ Concepts,” 212-228; Olson, “The Power to Name,” 639, 646.

${ }^{106}$ Given and McTavish, “What’s Old is New Again,” 9; Trant, “Emerging Convergence,” 369.

${ }^{107}$ Given and McTavish, “What’s Old is New Again,” 27-28.
} 
The Case of LLACE: Challenges, Triumphs, and Lessons of a Community Archives

revitalize and expand practice, ${ }^{108}$ understanding work already completed by community archives will become even more important. Community archives may be seen as part of the vanguard of this renewed interest in GLAM and provide models for integrated professional practice.

\section{Conclusion}

Community archives, like LLACE, demonstrate the importance of creating and maintaining spaces in communities for people to come together to collect, preserve, share, and learn from their histories. Dedicated individuals make possible the continued viability of community archives and their willingness to share their time and knowledge with researchers makes possible the continued addition of information on these important archives to our archival literature. Through understanding and appreciating the community archives movement, archivists can advance professional theory and practice to be more inclusive and collaborative so that their institutions better represent diversity of their communities.

\footnotetext{
${ }^{108}$ Kalfatovic, Kapsalis, Spiess, Van Camp, and Edson, “Smithsonian Team Flickr,” 267; Paul F. Marty and Michael B. Twidale, “Museum Informatics Across the Curriculum: Ten Years of Preparing LIS Students for Careers Transcending Libraries, Archives, and Museums,” Journal of Education for Library and Information Science 52, no. 1 (2011): 9.
} 